\title{
Verzeichnis der zu erläuternden Abkürzungen.
}

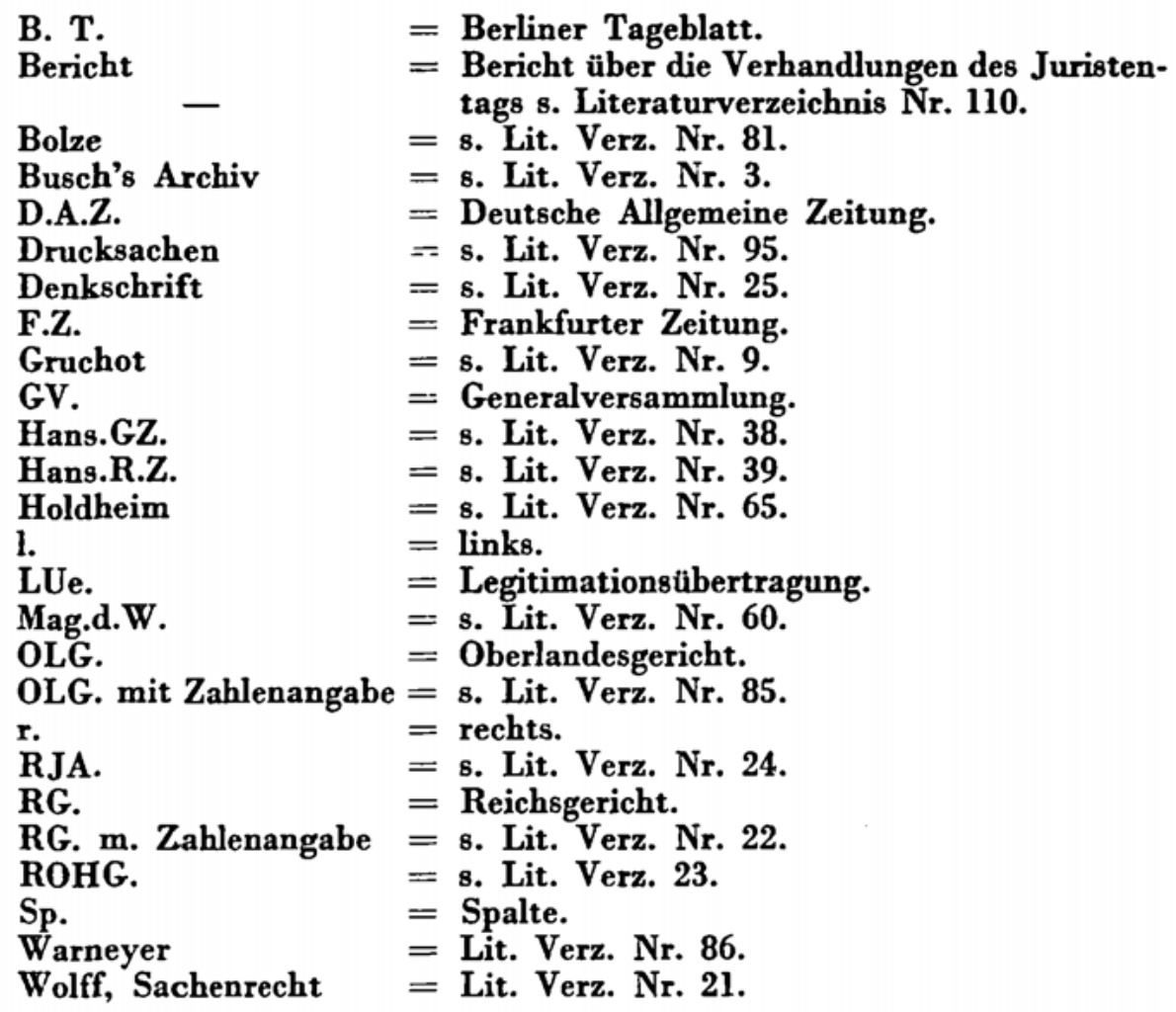

Soweit das Literaturverzeichnis Verwechselungen ausschlieBt, werden Verfasser ohne Angabe eines Schrifttitels angeführt. 
